\title{
E-Books in Swedish Public Libraries: Policy Implications
}

\author{
Elena Maceviciute and Tom D. Wilson
}

Swedish School of Library and Information Science, University of Borås, Allégatan 1, Borås, Sweden elena.maceviciute@hb.se, tom.wilson@hb.se

\begin{abstract}
The aims of the paper are: review the situation of e-books delivery in the Swedish public libraries (as it looked at the end of 2012); identify the barriers that public libraries encounter in providing access to e-books; highlight the policy-related problems of e-book provision through public libraries. A survey was carried out in October, 2012 of all public libraries in Sweden. 291 questionnaires were issued. 185 were completed, response rate was 63.3\%. The provision of an e-book service has arisen as a result of either demand or an ideological belief that the ethos of democratic values and equality of access requires libraries to offer material in all media. Librarians find the situation of e-books provision through libraries unsatisfactory: the provider of titles removes them from the catalogue without warning or explanation, there are too few titles for children and students, and access to popular titles is delayed.
\end{abstract}

Keywords: e-books, public libraries, information policy, Sweden.

\section{Introduction}

Sweden is among the top countries with regard to the penetration of broadband, internet, mobile technology, and internet usage in global surveys. The Swedish Statistical Bureau stated that 93\% of Swedish population aged 16-74 had internet access at home in 2011 [1, p. 247]. According to ITU data, internet penetration in Sweden is $92.9 \%$ (third place in the world after Iceland and Norway) and the literacy rate is $99 \%$ [2]. But the picture is different if we look at e-book production and use in Sweden. According to Bohlund [3] e-books accounted for only $1 \%$ of book production in Sweden in 2011, while Nordicom figures show that only $0.5 \%$ of Swedish readers use an e-book on an average day [4]. The provision of e-books in Sweden is dominated by one provider Elib, which has a monopoly position as a result of being established by a consortium of the country's four major publishers. The model that Elib offers to public libraries includes a firm sum for each loan of an ebook (20 SEK= approx. €2.4). This is an attractive model for less popular books, but is increasingly expensive for popular titles.

These figures and models relate to only one type of e-books published by commercial publishers and distributed in the market for profit. Economic copyright for these books is in force and is held by authors or publishers. Most of these e-books have printed equivalents. There are other types of ebooks: digitised books or digital copies of the texts free of copyright or those that are in copyright but distributed freely by authors or producers. This presentation deals only with the first category, i.e., commercially distributed e-books.

In 2011 the National Library of Sweden produced a report mapping the problems of e-books in Swedish library activities [5]. The report stated that there was no problem with the acquisition and provision of e-books in academic libraries.

The report provided proof of scarcity of the content in local languages in e-book format and the lack of a convenient business model [5, p. 21-23]. Despite this the latest statistics show that, in 2012, ebook loans from public libraries have increased $65 \%$ in comparison with 2011 and $289 \%$ in comparison with 2009. [6, p. 27].

A team from the SSLIS has conducted a census with all Swedish public libraries regarding their work with e-books and the problems arising from this novel activity. 


\section{Research Method}

The aims of this short paper are:

1 - 'To review the situation of the e-books' delivery to the users in the Swedish public libraries (as it looked at the end of 2012)

2 - To identify the barriers that public libraries encounter in providing access to e-books to their users

3 - To highlight the policy-related problems of the e-books provision through public libraries in Sweden.

A survey was carried out in October, 2012 of all public libraries in Sweden. A total of 291 questionnaires was issued and 225 or $77.3 \%$ began to complete the questionnaire. 185 fully completed it, an effective response rate, after three follow-up messages, of $63.6 \%$. The SurveyMonkey online survey service was used for the study. The percentages reported below are the percentage of people responding to a specific question.

The questionnaire was composed of 35 mainly closed questions, in Swedish, with some open questions or follow-up questions that allowed for open responses. The questions were grouped into 11 categories, as follows: Introduction, Policy for handling e-books, Access to e-books, License agreements with suppliers, Inclusion of e-books in the library catalogue, User training, How does ebook provision affect the relationship with the existing book suppliers, Assessment of user demand and satisfaction, The need for a library consortium for e-book purchases, Provision of e- books in Swedish, Future intentions (if e-books were not provided at present) .

\section{The State of E-Book Service Provision in Swedish Public Libraries}

\subsection{The E-Book Service Presence and Marketing}

Ninety-five per cent of libraries indicated that they offered an e-book service to their users; however, only 19 or $9.6 \%$ of those answering the question (i.e., 197) claimed to

have a formally documented policy underpinning the e-book service. Seventy percent (14) of those who did have a policy declared that it was publicly available and nine respondents indicated a Website address as the location of the policy while one sent a document file to the investigators. In most cases, however, the policy was simply a statement of the availability of e-books and the rules governing their lending.

When asked what factors determined the decision to offer e-books, the responses commented on the demand from readers, the need to develop services appropriate in the $21^{\text {st }}$ century, the fact that an ebook is simply another medium and should be offered just as print books are offered, and, importantly for some, the opportunity was offered to participate in county-wide collaborations in the provision of e-books. A number also commented that the service was a way of attracting new readers to the library. A typical response was:

The library will of course provide all kinds of media formats. Complement to the printed book, allowing more borrowers to read the book at the same time, no queues. Meet borrowers' requirements that we offer new technology, new media formats. Give borrowers the opportunity to test new ways of reading. 


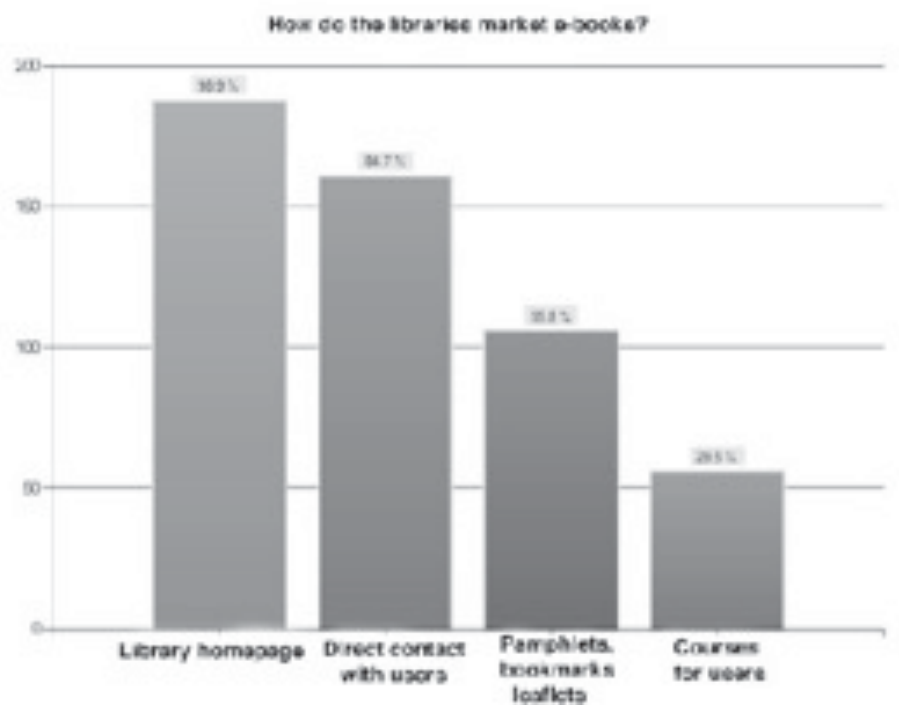

Fig. 1. Marketing means

As Fig. 1 shows, the most common way of marketing the service was through the library's Website (99\%), followed by direct contact with the users and the issuing of brochures, bookmarks and other documentation. Courses on the use of e-books were offered by a substantial minority of libraries $29 \%$.

\subsection{The Work with the Users of E-Book Services}

Although Sweden is a highly computer-literate country, for many people the e-book is a novel phenomenon. Not surprisingly, therefore, almost half of the respondents reported offering usereducation of some kind.

Topics in user education

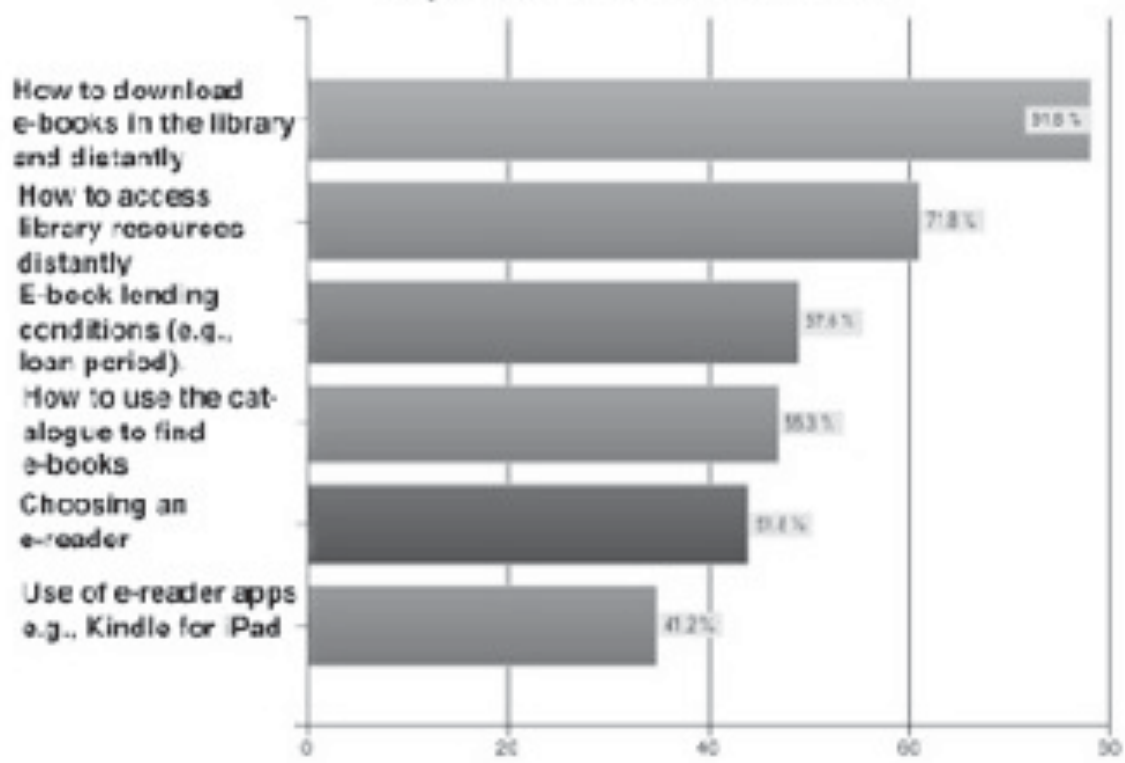

Fig. 2. User education: subjects

Most commonly, users were taught how to download the e-books when in the library, and remotely and how to use library resources in general at a distance. More than half of the libraries also gave 
instruction on how to use the catalogue to locate e- books, how to select an appropriate e-reader, and the conditions under which e-books could be borrowed. A smaller proportion (40\%) gave instruction on the use of apps such as the Kindle app for the iPad.

Only three libraries reported having carried out any reader satisfaction study in relation to e-books and only one of these reported the results, which were that readers were highly satisfied with the service. Ninety-eight per cent of the libraries responding to the question (i.e., 179 out of 182) had carried out no survey, but $91.4 \%$ of respondents intended to do so.

\subsection{The Barriers to Efficient E-Book Service}

E-book provision in Swedish public libraries is done through agreements with the provider, Elib. This is no doubt an efficient means of provision from the point of view of the publishers, but it presents severe problems from the perspective of the librarians. They feel very strongly that this mode of provision does not enable them to perform their normal professional responsibilities for the selection of material for their readers: they can only accept what the consortium chooses to make available. Furthermore, popular titles may not be made available in e-book form until months after the initial release, if at all, and titles may be withdrawn from the catalogue without notice. The librarians made comments such as:

We cannot decide what we want to buy, what literature we want to promote and offer to borrowers. It feels awful to be dependent on the vendor.

The publishers keep certain books in quarantine and remove the titles willy-nilly. The title choice is very small for adults and virtually non-existent for children and young people.

The librarians also do not have bibliographical control over the catalogue, since the user is transferred from the library's Web page to the Elib site and all the bibliographical data is at that site. Sixty-eight percent of the respondents attempted to deal with this by entering details of the available e-books into their own catalogues, usually simply transferring the data made available by Elib, but, in some cases (only 17\%), creating additional meta-data. We have here the emergence of a kind of hybrid digital library; one that is partly under the control of the library and partly under the control of the e-book provider.

Librarians have expressed the great dissatisfaction with the present pricing model for e-books. Almost $86 \%$ of respondents said that there was a need for a library consortium to be created to supply e-books. Sixty-nine per cent of respondents felt that the means for the supply of e-books in Swedish was less than satisfactory and when asked what should be done to improve things, said, in effect, that ways should be found to overcome the limitations of the current system. Suggestions included:

National agreement on different pricing model, state aid.

A wider range from the publishers' side, digitization of older titles, no waiting period for new titles...

Abolish the waiting period for new books in Swedish. Get an agreement that enables even translated titles to be offered.

More e-book providers would increase competition and hopefully improve the range. Another hope is that the smaller publishing companies could enter the market. 
In particular, access to literature for young people is quite poor. Since children use iPads and computers one-to-one in the school, this is a problem.

\section{Discussion and Conclusions}

The provision of an e-book service in Sweden has arisen as a result of either user demand or an ideological belief that democratic values and equality of access requires libraries to offer material in all media. But this position has some disadvantages: first, there is a lack of formal policy for service provision. By this we mean that no goals or objectives of service provision are set and there is no evaluation process to determine whether the goals are being satisfied.

A barrier to cost efficient service delivery lies in the fact that an e-book is treated as a digital file and, consequently, the public lending right act in Sweden does not apply to e-books. This is one reason why Elib can charge the SEK 20 for each loan directly to the library. There is the additional issue that an e-book is not bought by the library, but is licensed for use. It seems that marketing and user education is not active because of this lending cost to libraries.

The results of the survey reveal that librarians find this situation unsatisfactory: they find the operations of Elib in the provision of titles to be arbitrary, with titles being removed from the catalogue without warning or explanation, with too few titles for children and students, and with delays in access to popular titles. The establishment of a monopoly of this kind is believed to inhibit the entry of small publishers into the e-book market.

The latest statistics of library use in Sweden show a significant decline in loans of printed books, newspapers and journals, including the loans of children's books in public libraries. The increase in the loans of e-books does not compensate for this decrease [6, p. 27]. One of the reasons for this decrease may be this lack of suitable e- content in public libraries.

This is a considerable issue that has to be taken into account by the Parliament in adopting the library law with legal provisions for better access to media. The present proposal states that public libraries should ensure access free of charge to all literature regardless of publication form, but there is nothing that could change the conditions of e-book acquisition for public libraries [7]. The opposition and library community has already suggested changes to the Government proposal suggesting that the law should clearly state library responsibility to provide access without payment to all media, not only "literature". The demand is expressed for a clear national library strategy that will help to make access to library services equal for everyone. The proposals should be debated in early autumn by the Swedish Parliament.

Given the trends, discussed earlier, it seems highly improbable that the present situation in Sweden will persist. More libraries will be able to buy e-books directly from publishers from abroad and the pressure on Swedish publishers to adapt to this situation will be irrepressible. The leading role and initiatives of the National Library of Sweden will become more significant. The government's policies are likely to take more notice of the concerns of librarians and educational institutions in the light of the recent statistics reported above.

Acknowledgments. Our thanks go to all the librarians who participated in the survey. The study was carried out with the support of the Swedish Library Association. We also acknowledge the support of Swedish Research Council. 


\section{References}

1. CSB:PrivatpersonersAnvändningavDatorerochInternet(Usageofcomputersandinternet by private persons). Stockholm (2012), http://www.scb.se/statistik/_publikationer/ LE0108_2011A02_BR_IT01BR1201.pdf (retrieved May 26, 2013)

2. Internet World Stats: Top 50 Countries with the Highest Internet Penetration Rate (2011), http: // www. internetworldstats.com/top25.htm (retrieved May 28, 2013)

3. Bohlund K. Faktabanken, http: //forlaggare.se/faktabank (retrieved May 26, 2013)

4. Facht U.Aktuell Statistik om E-böcker, http://www.nordicom.gu.se/ common/ stat_xls/2189_3090_E-bokstatistik_antologi_2012.pdf (retrieved May 28, 2013)

5. Kungliga Biblioteket: När Kommer Boomen? En Kartläggning av E-boken i Sverige ur ett Biblioteksperspektiv. (When will the boom happen? A survey of the e-book in Sweden from a library perspective.) Svensk Biblioteksföreningen, Stockholm (2011)

6. NationalLibraryofSweden.Bibliotek2012.Kungligabiblioteket,Stockholm(2013)

7. Regeringensproposition2012/13:147.Nybibliotekslag, http://www.riksdagen.se/sv/Dokument-Lagar/Forslag/ Propositioneroch-skrivelser/Ny-bibliotekslag_H003147/ ?html=true (retrieved May 29, 2013) 